\title{
Structure and gametogenic potential of seminiferous tubules in ageing mice
}

\author{
R. G. Gosden, D. W. Richardson*, N. Brown and D. W. Davidson* \\ Department of Physiology, University Medical School, Teviot Place, Edinburgh EH8 9AG, and \\ *M.R.C. Reproductive Biology Unit, 37 Chalmers Street, Edinburgh EH3 9EW, U.K.
}

\begin{abstract}
Summary. The gametogenic potential of young male $\mathrm{CBA} / \mathrm{Ca}$ mice aged 4-5 months was compared with that of animals 20-23 months of age which had recently ceased to sire offspring. The older mice had substantially lower circulating levels of testosterone and smaller testes. Testicular and epididymal spermatozoa were reduced in number, had more abnormal forms and fewer were progressively motile. Ageing seminiferous tubules varied in their degree of functional atrophy from complete depletion of germ cells to maintenance of sperm production. They were enclosed by a thickened basal lamina and more collagenous connective tissue and occasionally allowed the penetration of lanthanum between Sertoli cells into the ad-luminal compartment. There was no evidence of autosensitization to sperm antigens.
\end{abstract}

\section{Introduction}

Ageing of the testis, like that of the ovary, involves a decreased output of sex steroids and gametes, though this does not usually result in a well-defined climacteric or transition from the reproductive to a post-reproductive phase of adult male life (Bishop, 1970; Vermeulen, Rubens \& Verdonck, 1972; Nieschlag, 1979). Morphological signs of testicular ageing can be recognized relatively early in maturity, the most conspicuous one being the appearance of atrophic tubules in men and other animals (Sasano \& Ichijo, 1969; Bishop, 1970).

In the present study an attempt was made to identify possible causes of tubule atrophy in the testes of ageing inbred mice by comparing their functional activity with their morphological appearance. In addition, it seemed necessary to search for signs of testicular autosensitization in these animals because this organ is susceptible to immunological injury and autoimmunity is a characteristic of ageing.

\section{Materials and Methods}

Animals. Young (4-5 months) and ageing (20-23 months) CBA/Ca male mice were obtained from the Department of Physiology colony where they were maintained at $23 \pm 1^{\circ} \mathrm{C}$ with a photoperiod of $14 \mathrm{~h} / \mathrm{day}$ and food and water ad libitum. All of these animals had previously sired offspring although animals of this colony rarely mate with or impregnate females after 20 months of age. They had been isolated from females at least 1 month before study. Each animal was killed by decapitation and trunk blood was collected and prepared as serum which was stored at $-18^{\circ} \mathrm{C}$ for steroid radioimmunoassay (see below).

The right cauda epididymidis and adjacent third of the vas deferens were dissected free of 
adhering tissue and incubated for $10 \mathrm{~min}$ at $36^{\circ} \mathrm{C}$ in $3 \mathrm{ml}$ tissue culture medium 199 containing Earle's salts and $20 \mathrm{~mm}$-Hepes buffer (Flow Laboratories, Irvine, Ayrshire). The medium was supplemented with $0.27 \mathrm{~mm}$-pyruvate, $3 \mathrm{mg}$ BSA (Sigma, London)/ml and $0.1 \mathrm{mg}$ gentamicin (Flow Labs) $/ \mathrm{ml}$. The epididymis was then cut in three places and at the base of the vas to allow spermatozoa to swim out. After a further incubation of $15 \mathrm{~min}$ the fluid was agitated gently and samples were withdrawn for light microscope examination. The percentage of motile spermatozoa was estimated from the proportion capable of forward progression.

The left testis and epididymis were each isolated, blotted gently to remove surface moisture, weighed and minced for $20 \mathrm{sec}$ in $2 \mathrm{ml}$ medium (as above) to produce a cell suspension (Polytron, Lucerne). The suspensions were vortex-mixed and prepared immediately for counting with a haemocytometer. Seminal vesicles were weighed after expression of their fluid contents. Finally, a routine post-mortem examination was carried out so that diseased animals could be excluded from study.

Light and electron microscopy. Testes were removed from animals immediately after death and fixed overnight in aqueous Bouin's fluid. Fixed tissues were embedded in paraffin wax, sectioned at $6 \mu \mathrm{m}$ and stained with haematoxylin and eosin. The spermatogenic activity of these organs was estimated by using the Sertoli cell number as a constant factor, and thus to obtain the "Sertoli cell ratio" (Skakkebaek \& Heller, 1973). The numbers of spermatogonia, spermatocytes and spermatids in 10-20 randomly selected tubules presenting an approximately circular cross-sectional profile were counted under oil-immersion $(\times 1000)$ and expressed as a ratio to the number of Sertoli cells sectioned through the nucleolus in the same tubule segment. Fine distinctions between cell stages were not made, although spermatids were classified into early and late forms which corresponded approximately to the Golgi and cap phases (1-7) and the acrosomal and maturation phases (8-12), respectively (Leblond \& Clermont, 1952). In addition, the cross-sectional diameters of 50 tubules in each testis were measured with an ocular micrometer.

Fresh testicular tissue was gently teased between fine needles to allow penetration of fixative for electron microscopy. The methods of tissue preparation were similar to those of Neaves (1973). Half of the tissue fragments from each animal were immersed in fixative containing lanthanum nitrate for the study of occlusive cell junctions. Tissue prepared in the same way from 15-day-old mice served to demonstrate the appearance of the tracer in tubules which lack occluding junctions between Sertoli cells (Vitale, Fawcett \& Dym, 1973).

Estimation of serum sperm-agglutinating activity. Blood was collected from the tail veins of conscious animals and prepared as serum. Although mainly comprising $\mathrm{CBA} / \mathrm{Ca}$ mice this group also included 3 young and 5 ageing $Q$-strain animals. A micro-agglutination method based on that developed for the rat was used for measuring sperm-agglutinating activity (Rümke \& Titus, 1970).

Sperm suspensions containing a high proportion of motile cells $(>60 \%)$ were obtained from the epididymides of syngeneic male mice. They were maintained at a concentration of about $10^{7}$ cells $/ \mathrm{ml}$ in the medium described above. Serum samples were heated for $30 \mathrm{~min}$ at $56^{\circ} \mathrm{C}$ to remove non-specific agglutinating activity, cooled and diluted with medium. Sperm suspensions were added to the diluted sera, agitated gently and incubated at $36^{\circ} \mathrm{C}$. Each tube was evaluated at 30-min intervals up to $3 \mathrm{~h}$; granular suspended or precipitated material was regarded as a positive reaction. When a positive reaction was obtained at dilutions of $1: 4$ or $1: 20$ they were tested at greater dilutions up to $1: 1280$. Each experiment contained negative control tubes (lacking serum) and positive control tubes (containing serum from animals previously immunized with autologous mouse testis in Freund's Complete Adjuvant).

Immunofluorescence. Since small numbers of plasma cells and local production of antibody might have been undetected by the above techniques, the distribution of immunoglobulin (Ig) in the testis and epididymis was examined by immunofluorescence. An indirect method was used: cryostat sections cut at $6 \mu \mathrm{m}$ were incubated with rabbit anti-mouse Ig, washed with PBS and 
then incubated with FITC-conjugated swine anti-rabbit Ig (Dako, Copenhagen). The presence of non-specific fluorescence was checked by incubating some sections without the first antibody. After thorough rinsing in PBS the sections were examined by u.v. fluorescence microscopy using incident illumination.

Radioimmunoassay. Serum testosterone and $5 \alpha$-dihydrotestosterone ( $5 \alpha$-DHT) were measured by radioimmunoassay following extraction with hexane:ether $(4: 1, \mathrm{v}: \mathrm{v})$ and separation by celite chromatography (Thorneycroft, Ribeiro, Stone \& Tillson, 1973). An antiserum was raised to testosterone in a goat using testosterone-3-carboxymethyloxime-BSA as the immunogen (Corker \& Davidson, 1978). The cross-reactivity of the antiserum with 16 steroids was analysed and found to be significant only for $5 \alpha$-DHT $(23.9 \%), 11 \beta$ hydroxytestosterone $(0.4 \%)$, oestradiol-17 $(0.2 \%)$ and $\Delta^{4}$-androstenedione $(0.1 \%)$. The antiserum to $5 \alpha$-DHT was raised to $5 \alpha$-dihydrotestosterone-3-carboxymethyloxime-BSA in a rabbit and this cross-reacted with testosterone $(57.0 \%), 5 \alpha$-androstan-3 $\beta, 17 \beta$ dicl (7.8\%) and $5 \beta$-DHT (3.0\%). The efficiencies of recovering known amounts of testosterone and 5 $\alpha$-DHT from serum were $81.0 \pm 6.7 \%$ and $87.8 \pm 8.5 \%$ respectively for the two steroids. The characteristics of the assays for testosterone and $5 \alpha$-DHT were as follows: sensitivity (10 and 5 $\mathrm{pg}$ respectively), intra-assay variation $(4.7$ and $9.0 \%$ respectively), interassay variation $(11.8$ and $14 \cdot 2 \%$ respectively).

Statistics. Because the form of the statistical distribution of data in the cytological studies was uncertain, the results were expressed by median values and ranges and analysed by ranking the data and applying Wilcoxon's test.

\section{Results}

The testes of old mice were conspicuously different from those of younger animals. They were smaller, somewhat flaccid and yellow-brown in coloration and the spermatozoa recovered from them were reduced in number and quality. The median values of testicular and epididymal spermatozoa in old animals were less than $30 \%$ of those in young individuals, and substantially fewer epididymal spermatozoa of the former group were motile and many were morphologically abnormal or decapitated forms (Table 1). The serum concentrations of testosterone but not $5 a$-DHT were reduced in old animals (Table 1). However, there was no parallel reduction in weight of the androgen-sensitive organs, epididymis and seminal vesicles, and the latter contained an abundant secretion.

Table 1. Comparison of the weights of reproductive organs and concentrations of spermatozoa and androgens in young and aged $\mathrm{CBA} / \mathrm{Ca}$ male mice

\begin{tabular}{|c|c|c|c|c|c|c|c|c|c|}
\hline \multirow[b]{2}{*}{$\begin{array}{c}\text { Age } \\
\text { (months) }\end{array}$} & \multirow[b]{2}{*}{$\begin{array}{l}\text { No. of } \\
\text { mice }\end{array}$} & \multicolumn{3}{|c|}{ Weight (mg) } & \multicolumn{2}{|c|}{$\begin{array}{l}\text { No. of spermatozoa } \\
\qquad\left(\times 10^{6}\right)\end{array}$} & \multirow{2}{*}{$\begin{array}{l}\text { Epididymal } \\
\text { sperm } \\
\text { motility (\%) }\end{array}$} & \multirow{2}{*}{$\begin{array}{c}\text { Serum } \\
\text { testosterone } \\
(\mathrm{ng} / \mathrm{ml})\end{array}$} & \multirow{2}{*}{$\begin{array}{c}\text { Serum } \\
5 \alpha-\mathrm{DHT} \\
(\mathrm{ng} / \mathrm{ml})\end{array}$} \\
\hline & & Testis & Epididymis & $\begin{array}{l}\text { Seminal } \\
\text { vesicles }\end{array}$ & Testis & Epididymis & & & \\
\hline $4-5$ & 8 & $\begin{array}{c}66 \\
(50-76)\end{array}$ & $\begin{array}{c}27 \\
(24-29)\end{array}$ & $\begin{array}{c}65 \\
(49-94)\end{array}$ & $\begin{array}{c}4 \cdot 3 \\
(3 \cdot 4-7 \cdot 8)\end{array}$ & $\begin{array}{c}17 \cdot 7 \\
(12 \cdot 4-22 \cdot 8)\end{array}$ & $\begin{array}{c}70 \\
(50-80)\end{array}$ & $\begin{array}{c}10 \cdot 37 \\
(0.39-29.91)\end{array}$ & $\begin{array}{c}0.21 \\
(0.11-0.56)\end{array}$ \\
\hline 22 & 8 & $\begin{array}{c}33^{* *} \\
(21-68)\end{array}$ & $\begin{array}{c}28 \\
(18-35)\end{array}$ & $\begin{array}{c}79 \\
(47-94)\end{array}$ & $\begin{array}{c}1 \cdot 2^{*} \\
(0.4-8 \cdot 8)\end{array}$ & $\begin{array}{c}4 \cdot 7^{* *} \\
(0 \cdot 6-12 \cdot 4)\end{array}$ & $\begin{array}{c}5^{*} \\
(0-70)\end{array}$ & $\begin{array}{c}0.26^{* *} \\
(0 \cdot 14-9 \cdot 44)\end{array}$ & $\begin{array}{c}0.12 \\
(0.06-0.28)\end{array}$ \\
\hline
\end{tabular}

Median values and ranges are given.

Values significantly different from those of young animals; ${ }^{*} P<0.02,{ }^{* *} P<0.01$.

The diminished number of testicular spermatozoa was paralleled by functional atrophy of individual tubules. Although the degree of atrophy varied greatly between segments of different tubules, serial examination suggested a greater uniformity along the length of individual tubules. 
A substantial proportion of tubule segments in aged testes were depleted of germ cells (median value $22 \%$ ) whereas every young tubule maintained active spermatogenesis (Pl. 1, Figs 1 and 2). The remnant of functional tubules in old animals exhibited widely varying degrees of germ cell attrition as was evidenced by their 'Sertoli cell ratio' (Table 2). The proportionate differences between 'Sertoli cell ratios' in the two age groups became progressively greater through successive stages of spermatogenesis. This result was apparently due to arrested development of spermatogonia and spermatocytes in some tubules rather than to a substantial increase in cell death, though quantitative estimates of death rates were not recorded. The reduction in spermatogenic activity was associated with reduced diameter of tubules $(P<0.01)$ and folding of the extracellular elements of the lamina propria (Pl. 1, Fig. 4).

Table 2. Quantitative cytological analysis of seminiferous tubules in young and aged $\mathrm{CBA} / \mathrm{Ca}$ mice

\begin{tabular}{cccccccc}
\hline & \multirow{6}{*}{$\begin{array}{c}\text { No. of } \\
\text { Age (months) }\end{array}$} & mice & Spermatogonia & Spermatocytes & Early spermatids & Late spermatids & $\begin{array}{c}\text { Sertoli cell } \\
\text { number }\end{array}$ \\
\cline { 3 - 7 } & 8 & $2 \cdot 4$ & $4 \cdot 3$ & $10 \cdot 3$ & $10 \cdot 6$ & 9 \\
$2-5$ & & $(1 \cdot 6-3 \cdot 4)$ & $(3 \cdot 0-5 \cdot 6)$ & $(7 \cdot 8-11 \cdot 5)$ & $(9 \cdot 1-13 \cdot 5)$ & $(7-11)$ \\
22 & 7 & $1 \cdot 1$ & $1 \cdot 5^{*}$ & $2 \cdot 2^{* *}$ & $1 \cdot 0^{* *}$ & 9 \\
& & $(0 \cdot 1-3 \cdot 3)$ & $(0-3 \cdot 9)$ & $(0-13 \cdot 5)$ & $(0-12 \cdot 9)$ & $(7-13)$ \\
\hline
\end{tabular}

Values are medians and ranges.

$\dagger$ Total no. of germ cells of a given type divided by the total no. of Sertoli cells in the same segment of tubule.

Values significantly different from those of young animals: ${ }^{*} P<0.05,{ }^{* *} P<0.01$.

Whereas extensive lengths of some tubules had lost their germ cell population, Sertoli cells were always present and were not depleted by ageing (Table 2). Their cytoplasm was highly vacuolated and sometimes contained dense bodies (lipofuscin granules). Where the lanthanum tracer material had penetrated the outer shroud of myoid cells further passage between Sertoli cells of young testes was restricted by occluding junctions between adjacent cell membranes. Meiotic and haploid germ cells were segregated in the adluminal compartment. By contrast with this condition in young adult animals, the tracer penetrated freely among the primary spermatocytes of the solid cords of prepubertal animals. The great majority of tubule segments in aged mice ( $>90 \%$ ) had sites of restricted permeability similar to those in young adults (Pl. 2, Fig. 6), but some segments with residual spermatogenesis showed a thin line of electron-opaque material extending into the interior of the tubule to surround spermatocytes and spermatids and form small pools between maturing germ cells (Pl. 3, Figs 7 and 8). The presence of lanthanum in the interior of tubules was taken to indicate permeable junctions between adjacent Sertoli cells because the alternative route of entry via the cut ends of tubules would presumably have allowed the tracer to penetrate young adult and ageing tissues similarly.

\section{PLATE 1}

Fig. 1. Intense spermatogenic activity in the testis of a 5-month-old $\mathrm{CBA} / \mathrm{Ca}$ mouse. $\mathrm{H} \& \mathrm{E}$, $\times 114$.

Fig. 2. The spermatogenic activity of seminiferous tubules in 22-month-old CBA/Ca mice was much reduced; some segments were devoid of germ cells and comprised only Sertoli cells (S). Venous walls were often thickened and contained basophilic material (V). Tissue shrinkage was usually more marked in old testes. H \& E, $\times 114$.

Figs 3 and 4. The basal lamina (arrow) lying beneath Sertoli cells (S) was thick, folded and multilaminar in old seminiferous tubules (Fig. 4) compared to the appearance in young mice (Fig. 3). There were conspicuous bundles of collagen fibrils $(\mathrm{C})$ between the internal and external laminas of old tubules. Glutaraldehyde and osmium, $\times 18200$. 


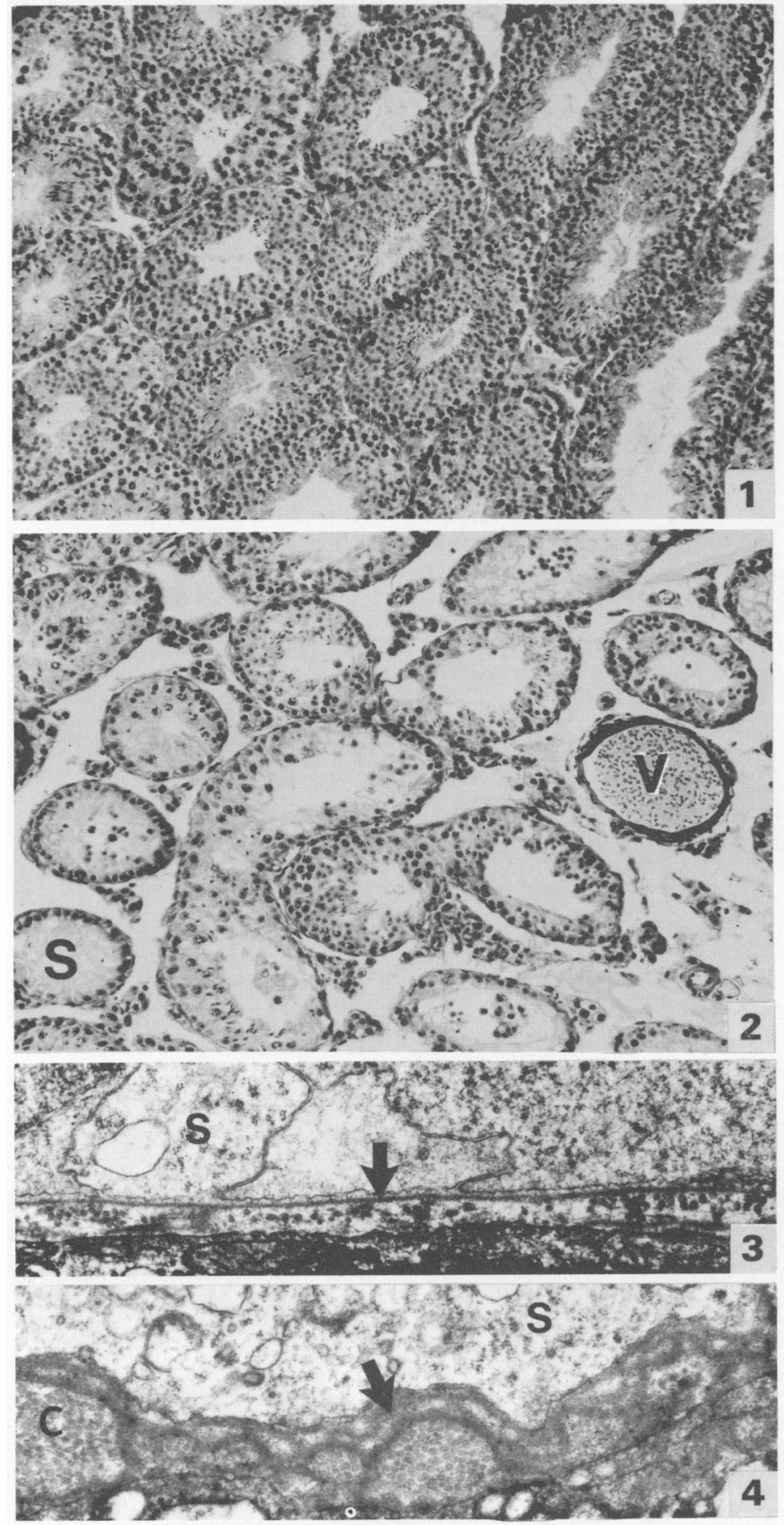

(Facing p. 130) 
PLATE 2
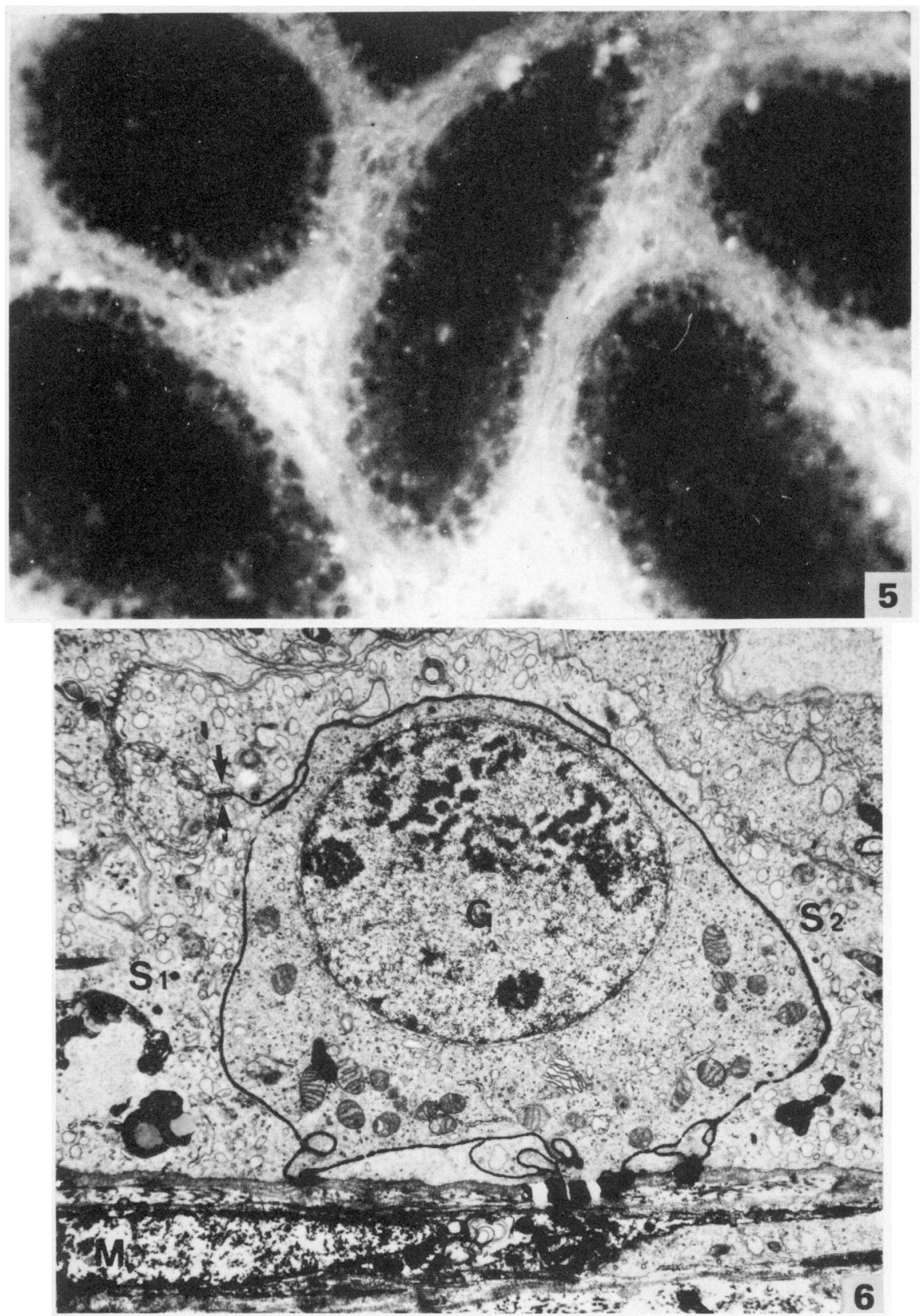

Fig. 5. The fluorescent antibody technique could not reveal $\mathrm{Ig}$ in the testicuiar tubules of old mice. Weak fluorescence in the basal zone of the tubules was mainly of a non-specific nature. $\times 390$.

Fig. 6. The integrity of the blood-testis barrier in old mice may be shown by exclusion of lanthanum (electron-opaque tracer material) from the ad-luminal compartment of seminiferous tubules. In this figure, a barrier to further penetration of the tracer was presented by tight junctions (arrow) between adjacent Sertoli cells $\left(S_{1}\right.$ and $\left.S_{2}\right)$. The spermatogonium type B shown here $(G)$ stands on the basal lamina and lies outside the so-called blood-testis barrier. Myoid cell (M). Glutaraldehyde and osmium, $\times 7800$. 


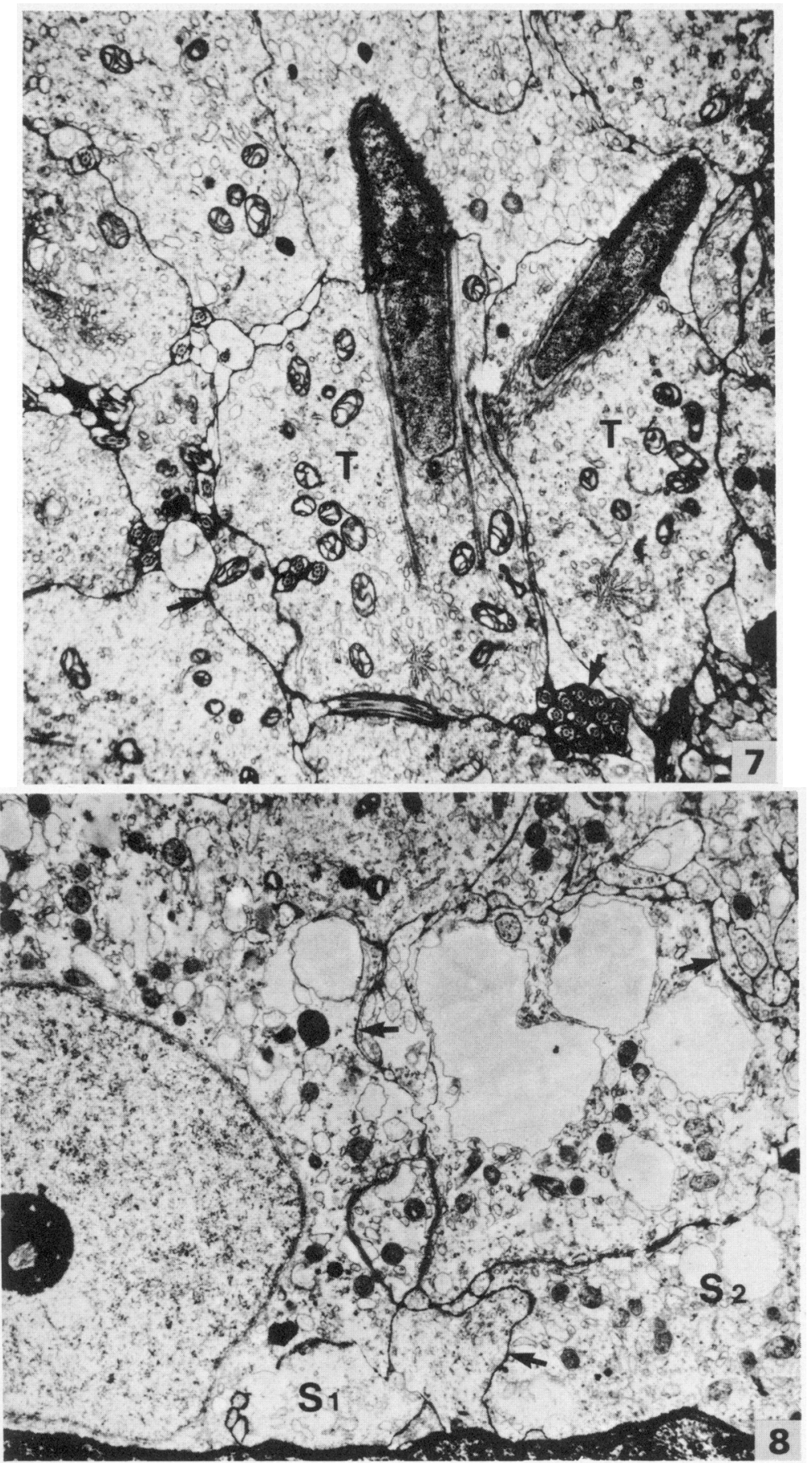


The internal basal lamina (i.e. adjacent to Sertoli cells) of aged tubules was folded, multi-laminar and substantially thicker than that in young animals (Pl. 1, Figs 3 and 4). It was also associated with bundles of collagenous connective tissue which had presumably been produced by myoid cells. These age differences were much less marked in the external lamina.

The atrophic changes in seminiferous tubules did not appear to have a specific pathological aetiology other than their relation to age. There was no evidence of obstruction of the lumen, of virus-like particles in the germinal epithelium or of an inflammatory reaction. Furthermore, there was no evidence of development of systemic or local autoimmune responses to testicular antigens. Circulating sperm-agglutinating antibodies were absent from young and old animals alike unless they had previously been sensitized by injection of testicular tissue (titre $\geqslant 20$ ) (Table 3). Moreover, inflammatory infiltrates of mononuclear cells were not found in aged animals and fluorescence due to immunoglobulin was confined to the interstitial tissue and, to a much lesser extent, the basal part of the tubules (Pl. 2, Fig. 5). Large numbers of autofluorescent granules were sometimes seen within tubules but they could always be distinguished from the evanescent apple-green appearance of FITC-conjugated antibody by their golden-yellow appearance and stable emission characteristics. They were probably the lipofuscin granules described above.

Table 3. Effect of age and immunization with syngeneic testis on sperm-agglutinating antibodies in sera of male mice

\begin{tabular}{cccc}
\hline Age (months) & Treatment & $\begin{array}{c}\text { No. of } \\
\text { mice }\end{array}$ & $\begin{array}{c}\text { No with sperm-agglutinating } \\
\text { activity (titre } \geq 20)\end{array}$ \\
\hline $4-5$ & - & 11 & 0 \\
$20-23$ & - & 13 & 0 \\
$4-5$ & FCA* & 3 & 0 \\
$4-5$ & FCA + testis & 5 & 5 \\
\hline \multicolumn{4}{c}{ * Freund's complete adjuvant. }
\end{tabular}

\section{Discussion}

These findings endorse earlier reports that substantial changes in testicular morphology and decrements in hormone and gamete production proceed during ageing in mice (Bishop, 1970; Bronson \& Desjardins, 1977). Other investigators have, however, reported that these functions are well-maintained in animals of advanced age (Finn, 1964; Eleftheriou \& Lucas, 1974; Nelson, Latham \& Finch, 1975). We cannot say whether the discrepancies between these studies result from differences of physiological age or of unidentified disease as is implied in the study of Nelson et al. (1975). However, the relatively early senescence of the testis during the lifespan of CBA/Ca mice corresponds to that of the ovary in this strain (Jones \& Krohn, 1961).

The reserves of epididymal spermatozoa were substantially reduced in ageing animals and presumably reflected diminished testicular production. The increased numbers of immotile and

\section{PLATE 3}

Figs 7 and 8. These micrographs show the appearance of lanthanum in the minority of old seminiferous tubules in which penetration was not impeded by junctional complexes between Sertoli cells (S). The tracer substance could be seen as a thin line of opaque material extending from the basal zone of the tubule through narrow extracellular spaces (arrows) (Fig. 8). The characteristic configuration of membranes at sites of tight junctions was not usually observed in these abnormal tubules. In some tubules where the tracer had penetrated the inner compartment (arrow) maturation of spermatids (T) was apparently proceeding normally in the apical epithelium (Fig. 7). Glutaraldehyde and osmium, $\times 7500$. 
morphologically abnormal spermatozoa in epididymides may also be attributed to testicular ageing since both maturation and transit time of epididymal spermatozoa are sensitive to the concentrations of androgen (Dyson \& Orgebin-Crist, 1973). Accumulation of informational errors in stem cells and genetic faults during gametogenesis are likely to be additional factors of importance (Bishop, 1970).

The maintenance of the size of the litters sired by ageing male mice (Finn, 1964; Franks \& Payne, 1970) may indicate that biologically significant deficits of the quantity and/or quality of epididymal sperm reserves do not occur, or occur after libido has waned. On the other hand, the frequent occurrence of insemination without subsequent impregnation in old CBA/Ca male mice may be an expression of oligospermia (R. G. Gosden, unpublished). The numbers and appearance of ejaculated spermatozoa should now be studied in these animals.

The lifespan of spermatogonial stem cells of mice appears to be limited by a randomly specified process and the numbers of these cells decrease exponentially with age (Suzuki \& Withers, 1978). The present results imply that there is an additional contribution to the reduced gametogenic function of the aged testis by the failure of germ cells to progress through successive stages of maturation. Since the loss of stem cells is progressive throughout adult life but maturational failure is only found in old age, different causal factors must be at work.

During the maturation of testicular function and in advance of the full progression of spermatogenic cells through meiosis, sites of restricted permeability develop between Sertoli cells. These occluding junctions isolate spermatocytes, spermatids and developing spermatozoa within an ad-luminal compartment which provides a physiologically unique environment for the development and immunological isolation of haploid germ cells (Dym \& Fawcett, 1970; Vitale et al., 1973; Setchell, 1978). If penetration of aged testicular tubules by lanthanum is a physiologically significant indication of a defective blood-testis barrier, the arrested development of spermatogonia and spermatocytes may be the result of an altered intra-tubular microenvironment. Consistent with this view, Neaves (1978) found lanthanum-permeable 'tight' junctions with reduced sperm production in the testes of vasectomized Lewis rats. However, further explanations of sperm cell attrition must be sought because the integrity of the blood-testis barrier was apparently maintained in the majority of atrophic tubule segments.

Maintenance of germ cell number and maturation in the testis is particularly sensitive to ischaemia, alterations in hormone balance and a variety of environmental factors including diet, ionizing radiation and temperature, though the mechanisms whereby they exert their control are poorly understood (Setchell, 1978). A number of these factors could play a part in senile testicular atrophy although the best documented one is the reduced production of testosterone by Leydig cells, which may be due in turn to LH deficiency (Bronson \& Desjardins, 1977). Furthermore, the amount of testosterone available to the germinal epithelium may be reduced even further by thickening of the barrier to diffusion, a condition which characteristically accompanies testicular cell injury by a wide variety of agencies (Pierce \& Nakane, 1969). The lamina propria may not only provide a significant barrier to the entry of hormones but also to nutrients and to the exchange of respiratory gases between the avascular tubule and the blood supply which may already be diminished (Ewing, 1967; Sasano \& Ichijo, 1969).

Several potentially damaging changes appear simultaneously in ageing testes. It is not yet possible to say which is primary; besides, their individual significance may be increased when in combination. Somewhat surprisingly, we found no experimental or morphological support for an autoimmune hypothesis of testicular ageing. Except for the lack of conspicuous cellular infiltration, the morphological appearance of many atrophic tubules in aged testes resembled that of testes suffering a low-grade autoimmune orchitis. Moreover, Rümke \& Titus (1970) reported low titres of naturally occurring anti-sperm antibodies in the serum of rats approximately 9-12 months old. There was no evidence of spontaneous testicular autoimmunity in ageing mice. The integrity of the blood-testis barrier in ageing mice, though probably defective in places, is presumably sufficient to prevent autosensitization even at advanced stages of testicular atrophy. 
We thank Kay Grant for technical assistance and Professor R. V. Short, F.R.S. and Professor W. E. Watson for advice and facilities.

\section{References}

Bishop, M.W.H. (1970) Ageing and reproduction in the male. J. Reprod. Fert., Suppl. 12, 65-87.

Bronson, F.H. \& Desjardins, C. (1977) Reproductive failure in aged $\mathrm{CBF}_{1}$ male mice: interrelationships between pituitary gonadotropic hormones, testicular function, and mating success. Endocrinology 101, 939-945.

Corker, C.S. \& Davidson, D.W. (1978) A radioimmunoassay for testosterone in various biological fluids without chromatography. J. Steroid Biochem. 9, 373-374.

Dym, M. \& Fawcett, D.W. (1970) The blood-testis barrier in the rat and the physiological compartmentation of the seminiferous epithelium. Biol. Reprod. 3, 308-326.

Dyson, A.L.M.B. \& Orgebin-Crist, M.-C. (1973) Effect of hypophysectomy, castration and androgen replacement upon the fertilizing ability of rat epididymal spermatozoa. Endocrinology 93, 391402.

Eleftheriou, B.E. \& Lucas, L.A. (1974) Age-related changes in testes, seminal vesicles and plasma testosterone levels in male mice. Gerontologia 20, 231-238.

Ewing, L.L. (1967) Effect of aging on testicular metabolism in the rabbit. Am. J. Physiol. 212, 1261-1267.

Finn, C.A. (1964) Influence of the male on litter size in mice. J. Reprod. Fert. 7, 107-111.

Franks, L.M. \& Payne, J. (1970) The influence of age on reproductive capacity in $\mathrm{C} 57 \mathrm{BL}$ mice. $J$. Reprod. Fert. 21, 563-565.

Jones, E.C. \& Krohn, P.L. (1961) The relationships between age, numbers of oocytes and fertility in virgin and multiparous mice. J. Endocr. 21, 469-495.

Leblond, C.P. \& Clermont, Y. (1952) Spermiogenesis of rat, mouse, hamster and guinea pig as revealed by the "periodic acid-fuchsin sulphurous acid" technique. Am. J. Anat. 90, 167-215.

Neaves, W.B. (1973) Permeability of Sertoli cell tight junctions to lanthanum after ligation of ductus deferens and ductuli efferentes. J. Cell Biol. 59, $559-572$.
Neaves, W.B. (1978) The effect of vasectomy on the testes of inbred Lewis rats. J. Reprod. Fert. 54, $405-411$.

Nelson, J.F., Latham, K.R. \& Finch, C.E. (1975) Plasma testosterone levels in C57BL/6J male mice: effects of age and disease. Acta endocr., Copenh. 80, 744-752.

Nieschlag, E. (1979) The male climacteric. In Female and Male Climacteric, pp. 133-139. Eds P. A. van Keep, D. M. Serr \& R. B. Greenblatt. MTP Press, Lancaster.

Pierce, G.B. \& Nakane, P.K. (1969) Basement membranes. Synthesis and deposition in response to cellular injury. Lab. Invest. 21, 27-41.

Rümke, Ph, \& Titus, M. (1970) Spermagglutinin formation in male rats by subcutaneously injected syngeneic epididymal spermatozoa and by vasoligation or vasectomy. J. Reprod. Fert. 21, 69-79.

Sasano, N. \& Ichijo, S. (1969) Vascular patterns of the human testis with special reference to its senile changes. Tohoku J. exp. Med. 99, 269-280.

Setchell, B.P. (1978) The Mammalian Testis. Paul Elek, London.

Skakkebaek, N.E. \& Heller, C.G. (1973) Quantification of human seminiferous epithelium. I. Histological studies in twenty-one fertile men with normal chromosome complements. J. Reprod. Fert. 32, 379-389.

Suzuki, N. \& Withers, H. R. (1978) Exponential decrease during aging and random lifetime of mouse spermatogonial stem cells. Science, N.Y. 202, 12141215.

Thorneycroft, I.H., Ribeiro, W.O., Stone, S.C. \& Tillson, S.A. (1973) A radioimmunoassay of androstenedione. Steroids 21, 111-122.

Vermeulen, A., Rubens, R. \& Verdonck, L. (1972) Testosterone secretion and metabolism in male senescence. J. clin. Endocr. Metab. 34, 730-735.

Vitale, R., Fawcett, D. W. \& Dym, M. (1973) The normal development of the blood-testis barrier and the effects of clomiphene and estrogen treatment. Anat. Rec. 176, 333-344.

Received 31 March 1981 